\title{
Occurrence of the non-indigenous brittle star Ophiothela cf. mirabilis Verrill, 1867 (Echinodermata, Ophiuroidea) in natural and anthropogenic habitats off Santa Catarina, Brazil
}

\author{
Jonathan W. Lawley, ${ }^{1}$ Adriana Carvalhal Fonseca, ${ }^{2}$ Edson Faria Júnior, ${ }^{3}$ Alberto Lindner ${ }^{4}$
}

1 Universidade de São Paulo, Instituto de Biociências, Departamento de Zoologia, Rua do Matão, travessa 14, 101, 05508-090, São Paulo, SP, Brazil. 2 Instituto Chico Mendes de Conservação da Biodiversidade, Reserva Biológica Marinha do Arvoredo, Rodovia Maurício Sirotsky Sobrinho, km 02, 88053-700, Florianópolis, SC, Brazil. 3 Instituto Brasileiro de Biodiversidade, Rua Senador Dantas, 20, 20031-205, Rio de Janeiro, RJ, Brazil. 4 Universidade Federal de Santa Catarina, Centro de Ciências Biológicas, Departamento de Ecologia e Zoologia, Rua João Pio Duarte Silva, 241, Edifício Fritz Müller, 88040-970, Florianópolis, SC, Brazil.

Corresponding author: Jonathan W. Lawley, jwlawley@ib.usp.br

\begin{abstract}
The brittle star Ophiothela cf. mirabilis, an ophiuroid introduced in the Atlantic, has expanded its range north to Trinidad and Tobago and south to Paraná, Brazil. By monitoring the coast of Santa Catarina, Brazil, with both recruitment plates in harbors and scuba diving, we were able to observe specimens of $O$. cf. mirabilis in both natural and anthropogenic habitats. This confirms its reported range extension of roughly $80 \mathrm{~km}$ south and emphasizes the importance of anthropogenic means for their spread and establishment.
\end{abstract}

\section{Key words}

Ophiuroid; introduction; exotic species; invasive species; Atlantic Ocean.

Citation: Lawley JW, Fonseca AC, Faria Júnior E, Lindner A (2018) Occurrence of the non-indigenous brittle star Ophiothela cf. mirabilis Verrill, 1867 (Echinodermata, Ophiuroidea) in natural and anthropogenic habitats off Santa Catarina, Brazil. Check List 14 (2): 453-459. https://doi. org $/ 10.15560 / 14.2 .453$

\section{Introduction}

The Ophiuroidea or brittle stars, as they are commonly called, are the largest group of living echinoderms and occur in all oceans from the intertidal to great depths (Stöhr et al. 2012). Most of them are 5-armed, while Ophiothela Verrill, 1867, a genus of epizoic ophiuroids, belongs to a guild that exhibits 6 arms, as well as fissiparity, a mode of asexual reproduction that, by dividing across the disk, produces clones with regenerating arms (Hendler and Brugneaux 2013). Ophiuroids within this genus were thought to be confined to Pacific waters (Clark 1976).
In 2000, Ophiothela cf. mirabilis Verrill, 1867 was first observed in the Atlantic, off the southeastern coast of Brazil, in Ilha do Pai, Rio de Janeiro (Hendler et al. 2012). In 2004 it was seen off Bahia, northeastern Brazil, and in 2009 on the Paraná coast, in southern Brazil, as well as in intermediate locations in São Paulo and Espírito Santo; its range was extended to encompass approximately 1,800 $\mathrm{km}$ of coastline (Hendler et al. 2012). Later from 2011 to 2014, new observations were made not only further north in Brazil (Pernambuco; Mantellato et al. 2016), but also in French Guinea and in the Caribbean, including Tobago (Hendler and Brugneaux 2013) and St Vincent (Hendler 


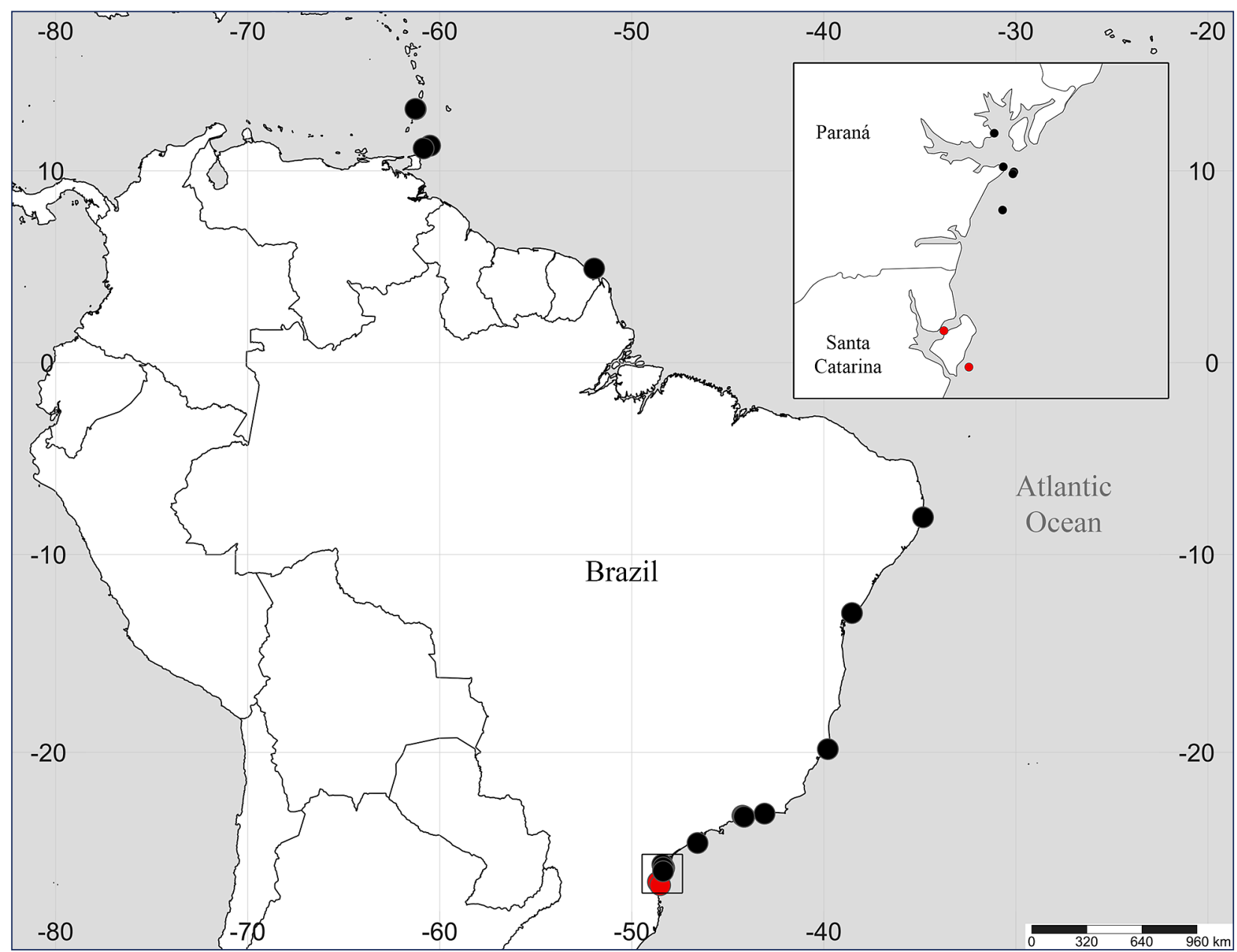

Figure 1. Occurrence of Ophiothela cf. mirabilis in the Western Atlantic. Black circles represent sites where Ophiotela cf. mirabilis was already recorded; red circles represent the records presented in this study, which are detailed on the inset map.

et al. 2012), the northernmost record in the Atlantic so far (Fig. 1, Table 1).

Although Pacific specimens of $O$. cf. mirabilis vary in color, the Atlantic representatives are nearly all yellow-orange, which indicates the prevalence of a single lineage, as well as a single introduction (Hendler et al. 2012). Nevertheless, the little that is known of its biology agrees with the pattern of dispersal and colonization seen in the Atlantic. Their hooked arm spines help them attach to a multitude of hosts, which can include macroinvertebrates that foul ships' hulls; the fissiparous asexual reproduction can aid the establishment in new localities; and sexual reproduction could lead to larval dispersal through oceanic currents or even in ballast water (Hendler and Brugneaux 2013). The fact that $O$. cf. mirabilis is observed near harbors that are far apart from each other, indicates the potential for anthropogenic dispersal in the Atlantic (Hendler et al. 2012).

The multitude of hosts in which they are found includes sponges, cnidarians, ascidians, other echinoderms, algae, bryozoans, and even seahorses, which emphasizes a lack of host specificity and a lack of color association between the ophiuroid and its host in Atlantic waters (Mantellato et al. 2016). Nevertheless, in Mexican Pacific specimens of $O$. mirabilis, in which there is greater color variability, a significant association was identified between the color of the brittle star and the host, which differs from what occurs in the Atlantic (Granja-Fernández et al. 2014). This suggests a lack of predators or even the presence of a predator deterrent, such as chemical defense, in the Atlantic representatives (Mantellato et al. 2016). Also, the very high prevalence of $O$. cf. mirabilis suggests a potential negative effect for their Atlantic hosts (Mantellato et al. 2016). Nevertheless, these hypotheses are yet to be tested.

We provide the full details of our records of $O$. cf. mirabilis in the state of Santa Catarina, Brazil (as briefly reported in Mantellato et al. 2016, although without details, description or correct reference). These Santa Catarina records are presently the southernmost known occurrence in the Atlantic.

\section{Methods}

Our collections began in December 2012, as part of the Marine Bioinvaders Project (Projeto Bioinvasores Marinhos, Programa Costa Atlântica V/2012, SISBIO collection permit 33662), through which recruitment granite plates were installed in 3 harbors along the Santa Catarina coast and monitored monthly until December 
Table 1. Updated geographic distribution of Ophiothela cf. mirabilis in the Atlantic. Coordinates in italic type are approximations based on the source's accounts.

\begin{tabular}{|c|c|c|c|c|c|c|}
\hline Country & State/ region & $\begin{array}{l}\text { Locality (as mentioned in } \\
\text { sources) }\end{array}$ & $\begin{array}{l}\text { Year of first } \\
\text { observation }\end{array}$ & Latitude & Longitude & Source \\
\hline \multirow{2}{*}{$\begin{array}{l}\text { Saint Vincent and the } \\
\text { Grenadines }\end{array}$} & & Several more Vincentian sites & 2012 & 13.1783 & -061.2661 & Hendler et al. 2012 \\
\hline & Saint Andrew & Campden Park Bay & 2011 & 13.1703 & -061.2496 & Hendler et al. 2012 \\
\hline \multirow[t]{3}{*}{ Trinidad and Tobago } & Tobago & Goat Island & 2013 & 11.3007 & -060.5186 & Hendler \& Brugneaux 2013 \\
\hline & & Little Tobago & 2013 & 11.2957 & -060.5017 & Hendler \& Brugneaux 2013 \\
\hline & & Store Bay & 2013 & 11.1553 & -060.8411 & Hendler \& Brugneaux 2013 \\
\hline French Guiana & & Les Battures & 2012 & 04.9268 & -051.9586 & Hendler \& Brugneaux 2013 \\
\hline \multirow[t]{18}{*}{ Brazil } & Pernambuco & & 2014 & -08.0803 & -034.8349 & Mantellato et al. 2016 \\
\hline & Bahia & Farol da Barra & 2004 & -13.0093 & -038.5329 & Hendler et al. 2012 \\
\hline & Espírito Santo & From São Paulo to Espírito Santo & & -19.8422 & -039.7895 & Hendler et al. 2012 \\
\hline & Rio de Janeiro & Ilha do Pai & 2000 & -22.9856 & -043.0854 & Hendler et al. 2012 \\
\hline & & Ilha Grande, Lagoa Azul & 2014 & -23.0841 & -044.2356 & Mantellato et al. 2016 \\
\hline & & Ilha Grande, Barretos & 2014 & -23.1040 & -044.1925 & Mantellato et al. 2016 \\
\hline & & Ilha Grande, Morcegos & 2014 & -23.1303 & -044.1491 & Mantellato et al. 2016 \\
\hline & & Ilha Grande, Abraãozinho right & 2014 & -23.1336 & -044.1509 & Mantellato et al. 2016 \\
\hline & & Ilha Grande, Abraãozinho left & 2014 & -23.1344 & -044.1542 & Mantellato et al. 2016 \\
\hline & São Paulo & Araçá Bay & 2012 & -23.8167 & -045.4000 & Alitto et al. 2016 \\
\hline & & From São Paulo to Espírito Santo & & -24.3931 & -046.5757 & Hendler et al. 2012 \\
\hline & Paraná & Baleia Rock & 2013 & -25.4138 & -048.4063 & Bumbeer \& Rocha 2016 \\
\hline & & Techint Pier & 2012 & -25.5536 & -048.3648 & Bumbeer \& Rocha 2016 \\
\hline & & Ilha do Mel & 2009 & -25.5748 & -048.3161 & Hendler et al. 2012 \\
\hline & & Galheta Island & 2013 & -25.5830 & -048.3206 & Bumbeer \& Rocha 2016 \\
\hline & & Currais Archipelago & 2012 & -25.7334 & -048.3680 & $\begin{array}{l}\text { Bumbeer \& Rocha } 2016 \\
\text { Bumbeer et al. } 2016\end{array}$ \\
\hline & Santa Catarina & São Francisco do Sul harbor & 2013 & -26.2334 & -048.6376 & This study \\
\hline & & Tamboretes Archipelago & 2014 & -26.3838 & -048.5227 & This study \\
\hline
\end{tabular}

2013. There were 5 metal sets per locality, each with three $25 \times 30 \mathrm{~cm}$ square granite plates attached, hung directly into the water by steel ropes so that during low tide they would still be at a minimum of $2 \mathrm{~m}$ underwater. During each monitoring event, the metal sets were lifted and placed in a container with seawater from the site, as photoquadrats were taken and further observations were made, with few collections and minimal alterations to the biota on the plates. Plates were returned to the water until the next monitoring event.

The study sites were the piers of São Francisco do Sul harbor (26 $\left.16^{\prime} 00^{\prime \prime} \mathrm{S}, 048^{\circ} 38^{\prime} 15^{\prime \prime} \mathrm{W}\right)$, Centro Nacional de Pesquisa e Conservação da Biodiversidade Marinha do

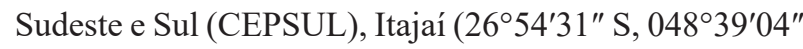
W), and Imbituba harbor ( $\left.28^{\circ} 13^{\prime} 49^{\prime \prime} \mathrm{S}, 048^{\circ} 39^{\prime} 06^{\prime \prime} \mathrm{W}\right)$. All of the sites are in harbors or very near them, which commonly characterizes anthropized areas. Furthermore, the São Francisco do Sul and Imbituba harbors are on or very near the coast, while CEPSUL is almost $2 \mathrm{~km}$ from the shore, in the Itajaí-Açú river.

Scuba dives were also made along the state's rocky shores as part of the Marine Bioinvaders Project and another project, the Marine Biodiversity of Santa Catarina Project (UFSC/FAPESC 4302/2010-8). These dives were performed regularly, often more than once a month, from 2010 to 2014, and included not only the assessment of exotic and invasive species, but also the study of the benthic community and environmental variables monitored by data loggers.
Five specimens from the São Francisco do Sul harbor were collected and identified under a stereomicroscope. These specimens were later fixed in $100 \%$ ethanol and donated to the echinoderm collection of the Museu Nacional in Rio de Janeiro (EQMN) for more detailed molecular and morphological studies that are currently ongoing for $O$. cf. mirabilis in the Atlantic (Tavares and Ventura unpublished).

\section{Results}

Records. Brazil: Santa Catarina. São Francisco do Sul harbor, recruitment granite plates, depth $2 \mathrm{~m}\left(26^{\circ} 14^{\prime} 00^{\prime \prime} \mathrm{S}\right.$, $048^{\circ} 38^{\prime} 15^{\prime \prime}$ W), Jonathan W. Lawley and Adriana Carvalhal Fonseca, January-December 2013, many individuals throughout the year (EQMN 4425, 5 specimens); Acaraí State Park: Tamboretes Archipelago, depth 7 m (26 $23^{\prime} 2^{\prime \prime}$ S, 048 31'22" W), Jonathan W. Lawley and Edson Faria Júnior, January 2014, dive survey, many individuals.

During monitoring of the recruitment granite plates, the non-indigenous $O$. cf. mirabilis was observed exclusively in the São Francisco do Sul harbor (Fig. 2A-C). In this locality, the alien ophiuroid was observed every month, although density was much higher from January to April (up to 60 individuals per plate) than from May to December (occasionally only a couple of individuals per plate) (Fig. 2B, C). The ophiuroids were observed associated with encrusting macroinvertebrates, such as ascidians, 

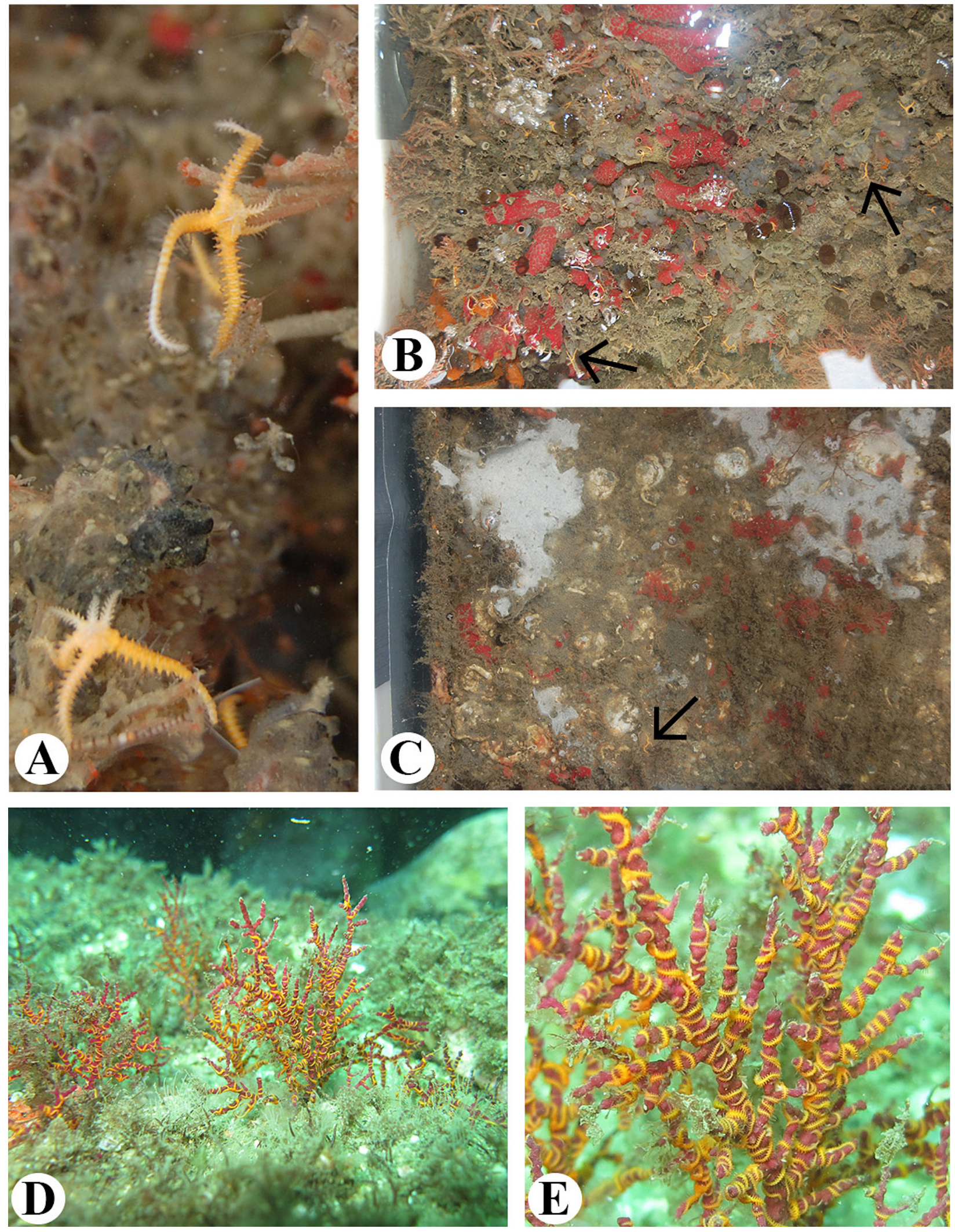

Figure 2. Records of Ophiotela cf. mirabilis in artificial and natural environments in Santa Catarina state, southern Brazil. A. Detail of some specimens found in recruitment granite plates at São Francisco do Sul harbor (ca $1.7 \mathrm{~mm}$ disc diameter for both specimens). B. A quarter of a recruitment plate in March 2013, with more than 30 individuals of Ophiotela cf. mirabilis. C. A quarter of the same recruitment plate in July 2013, with only 1 ophiuroid found; black arrows point to the ophiuroid individuals. D. Individuals of Ophiotela cf. mirabilis found in natural environment covering the gorgonian Leptogorgia punicea in Tamboretes Archipelago. E. Detail of ophiuroids wrapped around the same gorgonian. 

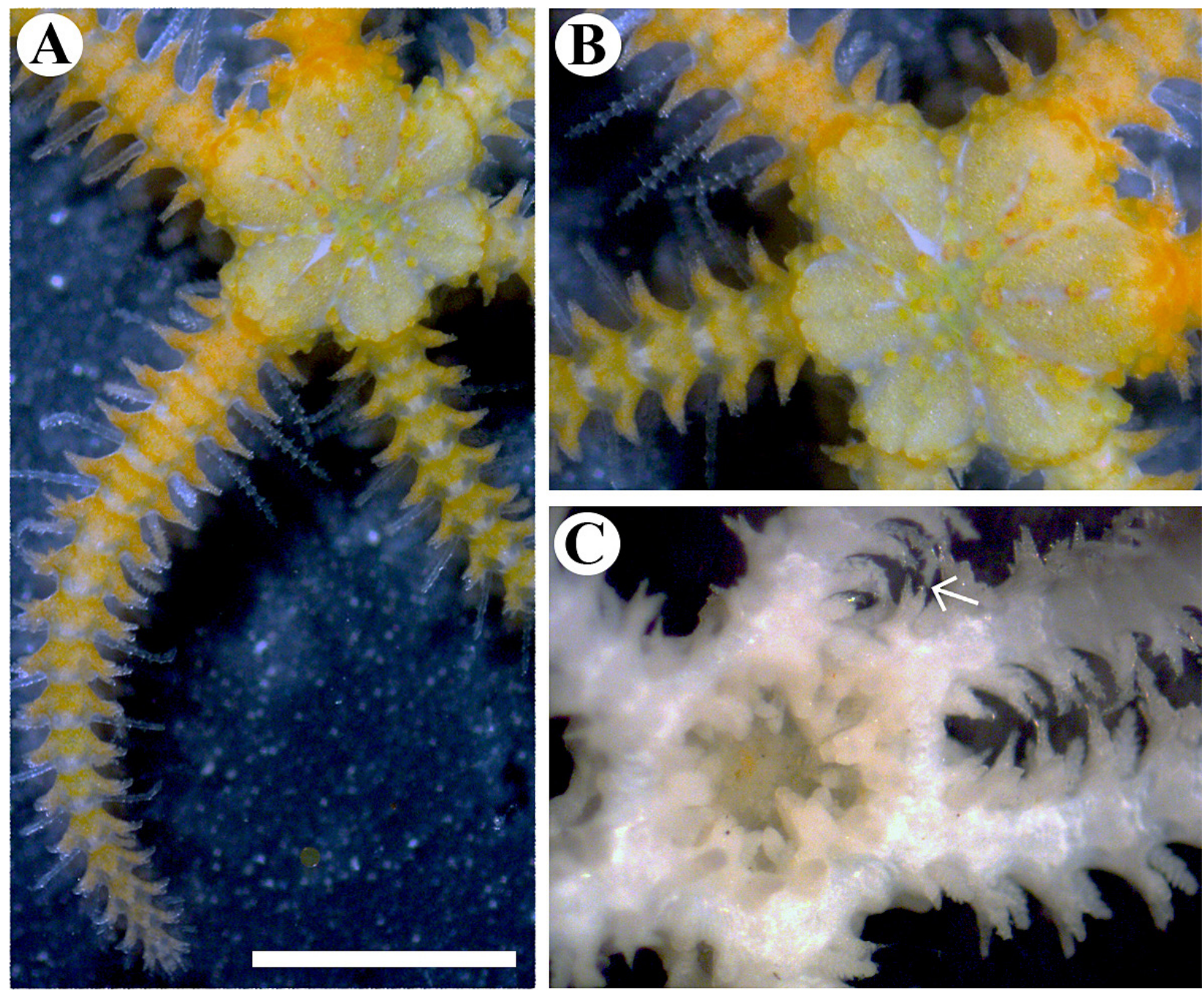

Figure 3. Morphological characteristics of Ophiotela cf. mirabilis collected in Santa Catarina state, southern Brazil. A. Dorsal view of a live specimen, with detail on disc and 1 complete arm. Scale bar $=1.5 \mathrm{~mm}$. B. Details of the lobulated disc and dorsal arm plates, both covered with round grains. C. Ventral view of the specimen after fixation, with detail on the jaw and its rounded dental papillae, as well as on the spines of the lateral arm plate; the white arrow points to a hook at the tip of a spine.

bryozoans, cnidarians, and sponges (Fig. 2B, C). Also, throughout the study period, most of the specimens had 3 arms much shorter than the others (Fig. 2A), or in some cases only 3 arms in total (Fig. 2C, arrow points to specimen).

While performing scuba dive surveys in the Tamboretes Archipelago $\left(26^{\circ} 23^{\prime} 2^{\prime \prime} \mathrm{S}, 048^{\circ} 31^{\prime} 22^{\prime \prime} \mathrm{W}\right)$, a natural habitat in the Acaraí State Park off the northern coast of Santa Catarina, in January 2014, O. cf. mirabilis was recorded in high densities exclusively associated with the gorgonian Leptogorgia punicea (Milne Edwards \& Haime, 1877) (Fig. 2D, E).

Identification. Ophiuroids collected and photographed in the field were identified as Ophiothela cf. mirabilis based on the key and description present in Granja-Fernández et al. (2014), as well as on the original description by Verrill (1867). The specimens have a lobulated disk (disk diameter $=1.5-2.0 \mathrm{~mm}$ ) with scattered round unequal grains, and with 6 arms (Fig. 3A, B). Each lateral arm plate has 5-6 thorny arm spines with hooks at the tip, the middle spine usually the longest (Fig. 3C). The dorsal arm plates are also covered with rounded unequal grains, with intervals between these plates indicated by naked spaces (Fig. 3A, B). On the ventral (oral) side, tentacle scales are absent and ventral arm plates have rounded edges (Fig. 3C). Oral papillae are absent, while rounded dental papillae form a cluster in the apex of the jaw (Fig. 3C). Also, specimens are similar in size, color, and overall morphology to other specimens in the Atlantic (Hendler et al. 2012, Hendler and Brugneaux 2013). Nevertheless, even though the aforementioned morphological features are present in the species' description and used in an identification key (Verrill 1867, Granja-Fernández et al. 2014), proper identification of Atlantic specimens remains provisional, due to morphological similarity and lack of taxonomic resolution in the genus Ophiothela (Clark 1976, Hendler and Brugneaux 2013).

\section{Discussion}

In the recruitment granite plates monitored in the São Francisco do Sul harbor, the ophiuroid density decrease 
from May to December might be related to the lower density of encrusting macroinvertebrates present. These invertebrates, such as ascidians, bryozoans, cnidarians, and sponges, serve as host species for the establishment of $O$. cf. mirabilis (Mantellato et al. 2016), which only started regaining its previous density later in December when the density of the hosts increased. Furthermore, there seemed to be no host preference, as these brittle stars were not concentrated in any portion of the recruitment plates (Fig. 2B, C). This characterizes the described opportunistic and generalist behavior of $O$. cf. mirabilis in relation to its host species (Mantellato et al. 2016). Additionally, the observation on most specimens of 3 much shorter arms, or only 3 , of the usual total of 6 , indicates they were regenerating body structures after undergoing fission, which likely contributes for their establishment in new localities (Hendler and Brugneaux 2013).

In Tamboretes Archipelago, the ophiuroids were only observed associated with gorgonians, which is not unprecedented (Hendler and Brugneaux 2013, Mantellato et al. 2016). Moreover, this archipelago is near São Francisco do Sul Island (ca $5 \mathrm{~km}$ ), and approximately $40 \mathrm{~km}$ away from the São Francisco do Sul harbor, located in the Baía da Babitonga estuary (nearest waterway distances). This record in a nearby natural habitat emphasizes the potential spread of non-indigenous species from manmade focal points, such as harbors, in which they seem to establish. This has also been recorded for $O$. cf. mirabilis in the coast of Paraná (Bumbeer and Rocha 2016). These records confirm the range extension, as reported in Mantellato et al. (2016), of almost $80 \mathrm{~km}$ south into a new state in the Brazilian coast, which highlights the continuous spread of $O$. cf. mirabilis along the Western Atlantic and the importance of anthropogenic means for their establishment and, potentially, for their spread, such as the hulls of ships and ballast water. Dispersal by natural means could also occur, such as a planktonic larval stage spread by oceanic currents.

The absence of the ophiuroid in the CEPSUL can possibly be explained by the lower average salinity in the area (8 PSU; Schettini 2008) if compared to the other harbors monitored that are closer to shore (30.3-32.6 PSU; Cunha and Costa 2002, Schettini et al. 2005), which are more likely to have a greater richness of marine invertebrates. However, $O$. cf. mirabilis is also absent from Imbituba harbor, which might be explained by the higher frequency of temperatures below $16^{\circ} \mathrm{C}$ characteristic of waters south of the Island of Santa Catarina (Faria Júnior 2014); these brittle stars originate from tropical waters of the Eastern Pacific. The state of Santa Catarina is the southern limit of distribution for many species of corals, fish, and other invertebrates (e.g. Floeter et al. 2008, Capel et al. 2012). In that sense, the absence of the ophiuroids in the monitored localities mentioned above as well as other southernmost localities surveyed by scuba diving can be due to biological limitations, although it could also have yet to expand its distribution.

\section{Acknowledgements}

We thank the Instituto COMAR for transportation to Tamboretes Archipelago and Johnatas Adelir Alves and Paulo Eduardo Pereira Faria for their assistance with the scuba diving surveys. We also thank Diana Carla Floriani, Leandro Zago da Silva and other ICMBio staff for all the assistance during monitoring of recruitment plates, and to Instituto Ekko Brasil for support in other project logistics. This research was funded by FAPESC (4302/2010-8) and by the Programa Costa Atlântica (V/2012, Projeto Bioinvasores Marinhos).

\section{Authors' Contributions}

JWL, ACF, and AL conceived the experiment and JWL, $\mathrm{ACF}$, and EFJ collected the data. JWL wrote the text, and all authors reviewed, finalized, and approved the manuscript.

\section{References}

Alitto RAS, Bueno ML, Domenico MD, Borges M (2016) Annotated checklist of echinoderms from Araçá Bay, southeastern Brazil. Check List 12 (1): 1836. https://doi.org/10.15560/12.1.1836

Bumbeer J, Cattani AP, Chierigatti NB, Rocha RM (2016) Biodiversity of benthic macroinvertebrates on hard substrates in the Currais Marine Protected Area, in southern Brazil. Biota Neotropica 16 (4): e20160246. https://doi.org/10.1590/1676-0611-BN-2016-0246

Bumbeer J, Rocha RM (2016) Invading the natural marine substrates: a case study with invertebrates in South Brazil. Zoologia 33 (3): e20150211. https://doi.org/10.1590/S1984-4689zool-20150211

Capel KCC, Segal B, Bertuol P, Lindner A (2012) Corallith beds at the edge of the tropical South Atlantic. Coral Reefs 31 (1): 75-75. https://doi.org/10.1007/s00338-011-0818-3

Clark AM (1976) Tropical epizoic echinoderms and their distribution. Micronesica 12 (1): 111-118.

Cunha SR, Costa CSB (2002) Gradientes de salinidade e frequência de alagamento como determinantes da distribuição e biomassa de macroalgas associadas a troncos de manguezais na Baía da Babitonga, SC. Brazilian Journal of Aquatic Science and Technology 6 (1): 93-102. https://doi.org/10.14210/bjast.v6n1.p93-102

Faria Júnior E (2014) Distribuição espacial e estrutura das comunidades de antozoários (Cnidaria: Anthozoa) em substratos consolidados no litoral de Santa Catarina, Sul do Brasil. MSc dissertation, Universidade Federal de Santa Catarina, Florianópolis, 62 pp.

Floeter SR, Rocha LA, Robertson DR, Joyeux JC, Smith-Vaniz WF, Wirtz P, Edwards AJ, Barreiros JP, Ferreira CEL, Gasparini JL, Brito A, Falcón JM, Bowen BW, Bernardi G (2008) Atlantic reef fish biogeography and evolution. Journal of Biogeography 35 (1): 22-47. https://doi.org/10.1111/j.1365-2699.2007.01790.x

Granja-Fernández R, Herrerro-Pérezrul MD, López-Pérez RA, Hernández L, Rodríguez-Zaragoza FA, Jones RW, Pineda-López R (2014) Ophiuroidea (Echinodermata) from coral reefs in the Mexican Pacific. ZooKeys 406: 101-145. https://doi.org/10.3897/zookeys.406.6306

Hendler G, Migotto AE, Ventura CRR, Wilk L (2012) Epizoic Ophiothela brittle stars have invaded the Atlantic. Coral Reefs 31: 1005. https://doi.org/10.1007/s00338-012-0936-6

Hendler G, Brugneaux SJ (2013) New records of brittle stars from French Guiana: Ophiactis savignyi and the alien species Ophiothela mirabilis (Echinodermata: Ophiuroidea). Marine Biodiversity Records 6: e113. https://doi.org/10.1017/S1755267213000845

Mantellato MC, Vidon LF, Silveira RB, Menegola C, Rocha RM, Creed JC (2016) Host species of the non-indigenous brittle star Ophiothela mirabilis (Echinodermata: Ophiuroidea): an invasive 
generalist in Brazil? Marine Biodiversity Records 9: 8. https://doi org/10.1186/s41200-016-0013-x

Schettini CAF, Resgalla Junior C, Pereira Filho J, Silva MAC, Truccolo EC, Rörig LR (2005) Variabilidade temporal das características oceanográficas e ecológicas da região de influência fluvial do Rio Itajaí-Açu. Brazilian Journal of Aquatic Science and Technology 9 (2): 93-102. https://doi.org/10.14210/bjast.v9n2.p93-102

Schettini CAF (2008) Hidrologia do Saco da Fazenda, Itajaí, SC.
Brazilian Journal of Aquatic Science and Technology 12 (1): 49-58. https://doi.org/10.14210/bjast.v12n1.p49-58

Stöhr S, O’Hara TD, Thuy B (2012) Global diversity of brittle stars (Echinodermata: Ophiuroidea). PLoS ONE 7 (3): e31940. https:// doi.org/10.1371/journal.pone.0031940

Verrill AE (1867) Notes on the Radiata in the Museum of Yale College, with descriptions of new genera and species. Transactions of the Connecticut Academy of Arts and Sciences 1: 247-351. 